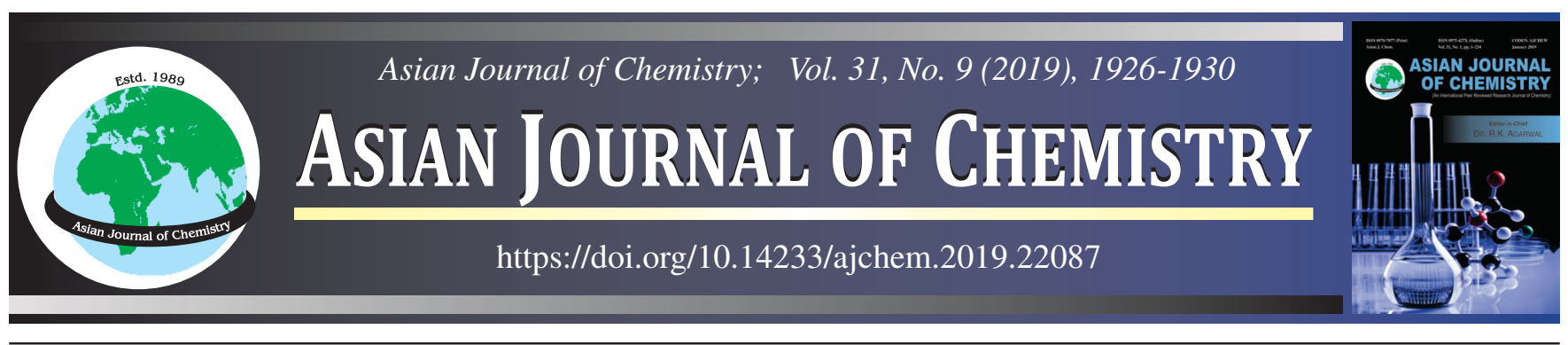

\title{
Synthesis, Characterization and Antibacterial Activities of New Bivalent Complexes of Transition Metals
}

\section{Veenu $\mathrm{Chugh}^{1}$, Sangeeta Sharma $^{2, *}$ and Rimpi Mehani Ne'e Chopra ${ }^{3}$}

${ }^{1}$ Department of Chemistry, Punjab Technical University, Jalandhar-144603, India

${ }^{2}$ Department of Applied Sciences \& Humanities, Shaheed Bhagat Singh State Technical Campus, Ferozepur-152004, India

${ }^{3}$ Department of Chemistry, Ramgarhia Girls College, Ludhiana-141003, India

*Corresponding author: E-mail: sangeetassharma70@gmail.com

Received: 19 March 2019;

Accepted: 10 April 2019;

Published online: 31 July 2019;

AJC-19478

This paper describes the synthesis, spectral studies and antimicrobial properties of the complexes with the formula $\left.\left[\mathrm{M}_{(\mathrm{C}} \mathrm{C}_{30} \mathrm{H}_{24} \mathrm{~N}_{4} \mathrm{O}_{2}\right) \mathrm{Cl}_{2}\right]$, where $\mathrm{M}=\mathrm{Fe}(\mathrm{II}), \mathrm{Co}(\mathrm{II}), \mathrm{Ni}(\mathrm{II}), \mathrm{Zn}(\mathrm{II})$ and $\mathrm{Cu}(\mathrm{II})$. These complexes were prepared by yield effective template condensation of hexamethylenediamine and 2,2-dihydroxyindane-1,3-dione(ninhydrin). The synthesized complexes were characterized by elemental analysis, infrared spectra, thermogravimetric analysis, Mass spectrum, ${ }^{13} \mathrm{C}$ NMR, molar conductance, electronic spectra, magnetic measurements. TGA and X-ray diffraction studies were used to ascertain the crystal structure and thermal stability of the complexes. The antimicrobial properties of complexes against two Gram-positive bacteria and two Gram-negative bacteria were evaluated by Agar well diffusion technique. Streptomycin and chloramphenicol were taken as standard antibiotics. The results shows that some of the complexes have potential to act as antibacterial agents.

Keywords: Macrocyclic complexes, Ninhydrin, Physiochemical techniques, Template synthesis, Antimicrobial.

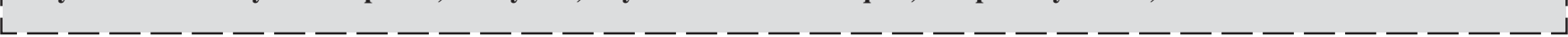

\section{INTRODUCTION}

Transition metals have a greater tendency to form complexes. The chelated complexes are stable [1] and easy to produce due to decrease in an entropic effect in the binding energy $[2,3]$ of molecule. As the position of the donor atom is fixed, the complexes acquire more stability than the polydentate ligands of the identical donors. Hence transition metal macrocycles are special case of the chelated complexes.

Moreover, the metal complexes find a large variety of applications in industry and medicine [4]. From classical times, various metal complexes have been used to treat a number of diseases like cancer. Platinum complexes such as cisplatin, carboplatin and oxaliplatin are the examples of the same. Transition metal complexes have been studied by many researchers for their antiviral, anticarcinogenic, antifertile, antifungal and antibacterial properties [5]. Benzofuran complexed with $\mathrm{CuCl}_{2}$, $\mathrm{FeCl}_{3}, \mathrm{ZnCl}_{2}$ and $\mathrm{LaCl}_{3}$ are reported to be antiviral in nature. Gold containing complexes are used to treat rheumatoid arthritis $[6,7]$. Complex containing copper, zinc and lanthanum have versatile applications in pharmaceutical field. Nonacetin, a class of macrocyclic antibiotic, binds with potassium and acts as a carrier for $\mathrm{K}^{+}$to transfer it across the lipid bilayers in the cell membrane.

Besides these applications, macrocycles containing nitrogen have a strong tendency to form stable complexes with transition metals. Hence we made this effort to prepare new nitrogen containing macrocycles. Schiff base macrocycles have a great importance in macrocyclic chemistry. The Schiff bases are obtained by the condensation of an active carbonyl compound and a primary amine. These macrocyclic ligands have imine or azomethine groups as an important structural part.

In continuation to our previous work, we have extended the synthesis of new complexes of bivalent metals by condensation of hexamethylenediamine (the primary amine) and ninhydrin (the active carbonyl). Two Gram-positive bacteria: Bacillus subtilis (MTCC 8509), Bacillus stearothermophilus (MTCC 8508) and two Gram-negative bacteria: Escherichia coli (MTCC 51) and Pseudomonas putida (MTCC 121) were used to check the efficacy of the synthesized complexes. It is sugges-

This is an open access journal, and articles are distributed under the terms of the Attribution 4.0 International (CC BY 4.0) License. This license lets others distribute, remix, tweak, and build upon your work, even commercially, as long as they credit the author for the original creation. You must give appropriate credit, provide a link to the license, and indicate if changes were made. 
ted that the synthesized complexes which are effective antibacterial, act on the ribosomes of the bacterial cell wall just like the standard streptomycin and chloramphenicol [8].

\section{EXPERIMENTAL}

The chemicals are used for the synthesis are all laboratory grade obtained from the Fischer scientific, Merck and NICE chemicals. Ninhydrin was of the brand: Pierce Protein Research Products. For the synthesis of these complexes we tried both the template and non-template methods. The yield of template synthesis was found to be more as compared to the non-template synthesis. The metal finely coordinates and nicely arranges the ligand fragments in its coordination sphere, thus assists the linking process of synthesizing the macrocyclic ligand, which in turn increases the yield. Hence template method is used for the synthesis of all these metal complexes.

General procedure: A solution of the metal ion $(5 \mathrm{mmol})$ was made by slowly adding methanol to the corresponding metallic salt. A hot methanolic solution of 2,2-dihydroxyindane-1,3-dione $(10 \mathrm{mmol})$ was poured in round bottom flask and mixed with the metal ion solution (about $50 \mathrm{~mL}$ ). This mixture was kept for refluxing for $0.5 \mathrm{~h}$, Hexamethylenediamine solution $(10 \mathrm{mmol})$ was then added and the refluxing was continued for 8-10 h, the time of refluxing depends upon the type of metal ions used. The resulting reaction mixture was allowed to concentrate first and then to stand for crystallization in desiccator for 2 days (Scheme-I). The product formed was filtered followed by washing with methanol and drying thoroughly.

Detection methods and analytical data: The condensation of hexamethylenediamine and ninhydrin results in formation of metal complexes which were coloured, solid non-hygroscopic, air stable and insoluble in most of organic solvents except DMF and DMSO. The purity of the synthesized macro- cyclic complexes was confirmed by TLC. All the complexes decomposed above $210{ }^{\circ} \mathrm{C}$ to a moist mass and did not show any sharp melting point. Their conductivity lies in the range 20-25 $\mathrm{ohm}^{-1} \mathrm{~cm}^{2} \mathrm{~mol}^{-1}$, which indicates non-ionic nature of the synthesized complexes [9].

The percentage of metal in all complexes was determined by complexometric titrations by using with eriochorme black$\mathrm{T}$, sulphosalicylic acid or mureoxide as external indicators. The metal complexes do not give precipitate with $\mathrm{AgNO}_{3}$, indicating absence of ionisable chloride. But when disintegrated using conc. $\mathrm{HCl} / \mathrm{HNO}_{3}$, they test positive for chloride ion.

The elemental analysis of $\mathrm{C}, \mathrm{H}$ and $\mathrm{N}$ was recorded at Elemental Analyzer for CHN (Thermo Scientific) from SAIF, Panjab University Chandigarh. The analytical data, given in Table-1, shows the formula for macrocyclic complexes as $\left[\mathrm{M}\left(\mathrm{C}_{30} \mathrm{H}_{24} \mathrm{~N}_{4} \mathrm{O}_{2}\right) \mathrm{Cl}_{2}\right]$ where $\mathrm{M}$ is $\mathrm{Fe}(\mathrm{II}), \mathrm{Co}(\mathrm{II}), \mathrm{Cu}(\mathrm{II}), \mathrm{Ni}(\mathrm{II})$ and $\mathrm{Zn}(\mathrm{II})$.

\section{RESULTS AND DISCUSSION}

Infrared spectra: The IR spectra of synthesized metal complexes were recorded on FT-IR spectrophotometer (Perkin Elmer Spectrum 400) in the range $4000-667 \mathrm{~cm}^{-1}$ by using $\mathrm{KBr}$ pellets at SAIF, CFL, Punjab University, Chandigarh. A strong band observed at $\sim 3300 \mathrm{~cm}^{-1}$ corresponding to N-H stretching vibrations in the IR spectrum of hexamethylenediamine was found to be absent in infrared spectra of the metal complexes. The origin of new strong band at $\sim 1650 \mathrm{~cm}^{-1}$ for $\mathrm{C}=\mathrm{N}$ stretching vibration indicates bonding of carbonyl group of ninhydrin and - $\mathrm{NH}_{2}$ group of hexamethylenediamine, confirming the formation of $-\mathrm{C}=\mathrm{N}-$ of macrocyclic frame $[10,11]$. The value of $-\mathrm{C}=\mathrm{N}$ stretching frequency at $1650 \mathrm{~cm}^{-1}$ suggests the involvement of nitrogen of azomethine towards metal atom coordination. Some important spectral bands shown in infrared spectra of all metal complexes are listed below in Table-1.

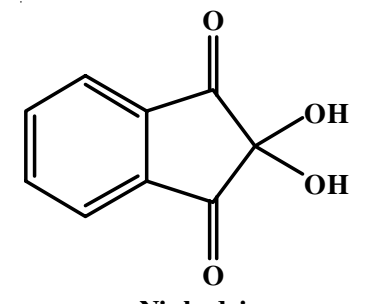

Ninhydrin

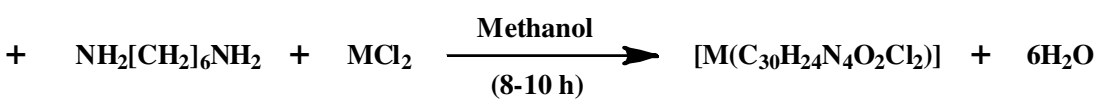

Hexamethylenediamine

Scheme-I

Macrocyclic complex

\begin{tabular}{|c|c|c|c|c|c|c|c|c|c|c|c|c|c|}
\hline \multicolumn{14}{|c|}{ Scheme-I } \\
\hline \multirow{3}{*}{ Complexes } & \multicolumn{13}{|c|}{$\begin{array}{l}\text { TABLE-1 } \\
\text { PHYSICO-CHEMICAL AND SPECTRAL DATA OF TRANSITION BIVALENT COMPLEXES }\end{array}$} \\
\hline & \multirow{2}{*}{ m.w. } & \multicolumn{4}{|c|}{$\begin{array}{l}\text { Elemental analysis (\%): } \\
\text { Found (Calcd.) }\end{array}$} & \multicolumn{3}{|c|}{$\operatorname{IR}\left(\mathrm{cm}^{-1}\right)$} & \multirow{2}{*}{$\begin{array}{c}\mathrm{Dq} \\
\left(\mathrm{cm}^{-1}\right)\end{array}$} & \multirow[t]{2}{*}{$\mathrm{B}^{\prime}$} & \multirow{2}{*}{$\beta$} & \multirow{2}{*}{$\beta \%$} & \multirow{2}{*}{$v_{2} / v_{1}$} \\
\hline & & $\mathrm{M}$ & $\mathrm{C}$ & $\mathrm{H}$ & $\mathrm{N}$ & $v(\mathrm{C}=\mathrm{N})$ & $v(\mathrm{C}=\mathrm{O})$ & $v(M-N)$ & & & & & \\
\hline$\left[\mathrm{Co}\left(\mathrm{C}_{30} \mathrm{H}_{24} \mathrm{~N}_{4} \mathrm{O}_{2}\right) \mathrm{Cl}_{2}\right]$ & 602 & $\begin{array}{l}9.75 \\
(9.8)\end{array}$ & $\begin{array}{l}57.2 \\
(58)\end{array}$ & $\begin{array}{l}3.85 \\
(3.9)\end{array}$ & $\begin{array}{l}9.1 \\
(9.3)\end{array}$ & 1625 & 1710 & 410 & 500 & 367 & 0.376 & 37.6 & 1.526 \\
\hline$\left[\mathrm{Ni}\left(\mathrm{C}_{30} \mathrm{H}_{24} \mathrm{~N}_{4} \mathrm{O}_{2}\right) \mathrm{Cl}_{2}\right]$ & 601 & $\begin{array}{l}9.71 \\
(9.8)\end{array}$ & $\begin{array}{c}58.1 \\
(59.9)\end{array}$ & $\begin{array}{l}3.87 \\
(3.9)\end{array}$ & $\begin{array}{l}9.12 \\
(9.3)\end{array}$ & 1624 & 1730 & 430 & 570 & 680 & 0.654 & 65.4 & 1.504 \\
\hline$\left[\mathrm{Fe}\left(\mathrm{C}_{30} \mathrm{H}_{24} \mathrm{~N}_{4} \mathrm{O}_{2}\right) \mathrm{Cl}_{2}\right]$ & 599 & $\begin{array}{c}9.1 \\
(9.34)\end{array}$ & $\begin{array}{c}58.9 \\
(60.1)\end{array}$ & $\begin{array}{l}3.79 \\
(4.0)\end{array}$ & $\begin{array}{l}9.21 \\
(9.3)\end{array}$ & 1677 & 1718 & 466 & 740 & 760 & 0.790 & 79.0 & 1.407 \\
\hline$\left[\mathrm{Cu}\left(\mathrm{C}_{30} \mathrm{H}_{24} \mathrm{~N}_{4} \mathrm{O}_{2}\right) \mathrm{Cl}_{2}\right]$ & 606 & $\begin{array}{c}1.2 \\
(1.04)\end{array}$ & $\begin{array}{c}58.1 \\
(59.4)\end{array}$ & $\begin{array}{l}3.81 \\
(3.9)\end{array}$ & $\begin{array}{l}9.32 \\
(9.4)\end{array}$ & 1684 & 1713 & 471 & 370 & - & - & - & 1.231 \\
\hline$\left[\mathrm{Zn}\left(\mathrm{C}_{30} \mathrm{H}_{24} \mathrm{~N}_{4} \mathrm{O}_{2}\right) \mathrm{Cl}_{2}\right]$ & 608 & $\begin{array}{c}1.01 \\
(1.07)\end{array}$ & $\begin{array}{c}58.0 \\
(59.2)\end{array}$ & $\begin{array}{l}3.82 \\
(3.9)\end{array}$ & $\begin{array}{c}9.0 \\
(9.2)\end{array}$ & 1670 & 1720 & 415 & - & - & - & - & - \\
\hline
\end{tabular}


Mass spectra: The mass spectra was recorded on mass spectrophotometer using SAIF, CFL, Panjab University, Chandigarh using LC-MS Spectrometer (Model Q-ToF Micro Waters). The mass spectra showed the final peaks at $602,601,606,599$ and 608 which indicates the peak due to $[\mathrm{M}]^{+}$ion. The molecular ion peak $[\mathrm{M}]^{+} \&[\mathrm{M}+4]^{+}$obtained in the mass spectra indicates the presence of two chlorine inside the coordination sphere. The major peaks are as follows: $\left[\mathrm{Co}\left(\mathrm{C}_{30} \mathrm{H}_{24} \mathrm{~N}_{4} \mathrm{O}_{2}\right) \mathrm{Cl}_{2}\right]^{+}=602$ \& 606, $\left[\mathrm{Ni}\left(\mathrm{C}_{30} \mathrm{H}_{24} \mathrm{~N}_{4} \mathrm{O}_{2}\right) \mathrm{Cl}_{2}\right]^{+}=601 \& 605,\left[\mathrm{Cu}\left(\mathrm{C}_{30} \mathrm{H}_{24} \mathrm{~N}_{4} \mathrm{O}_{2}\right) \mathrm{Cl}_{2}\right]^{+}$ $=606 \& 610,\left[\mathrm{Fe}\left(\mathrm{C}_{30} \mathrm{H}_{24} \mathrm{~N}_{4} \mathrm{O}_{2}\right) \mathrm{Cl}_{2}\right]^{+}=599 \& 603,\left[\mathrm{Zn}\left(\mathrm{C}_{30} \mathrm{H}_{24} \mathrm{~N}_{4} \mathrm{O}_{2}\right)\right.$ $\left.\mathrm{Cl}_{2}\right]^{+}=608 \& 612$.

Magnetic measurements and electronic spectra: Electronic spectra of the complexes were recorded on UV-vis spectrophotometer (Model Lambda 750 Perkin Elmer) at SAIF, CFL, Panjab University, Chandigarh. The magnetic measurements of First series of transition metals show an effective magnetic moment due to spin only moments of electrons.

Iron(II) complexes: The effective magnetic moment of iron(II) complex was observed at 4.95 B.M. at room temperature consisting of four unpaired electrons indicating high spin type complexes [12]. The electronic spectrum showed a peak at $10,500 \mathrm{~cm}^{-1}$ with a shoulder peak at $8000 \mathrm{~cm}^{-1}$. For $d$ configuration in ground state ${ }^{5} \mathrm{D}$ term is characterized. The electronic transition ${ }^{5} \mathrm{~T}_{2} \mathrm{~g} \rightarrow{ }^{5} \mathrm{Eg}$ transition is expected. These complexes may have $\mathrm{D}_{4} \mathrm{~h}$ symmetry and distorted octahedral structure has been proposed [13,14].

Cobalt(II) complexes: The magnetic moment of the cobalt(II) complex was recorded at room temperature and were observed at 4.15 B.M. which indicates the presence of three unpaired electrons and the electronic configuration as $3 d^{7} 4 s^{0}$. The electronic spectra of the cobalt(II) complexes recorded in DMSO suggests distorted octahedral geometry of complexes. These spectra show three absorption peaks at $8,550-9500 \mathrm{~cm}^{-1}$ $\left(v_{1}\right), 13,000-14,550 \mathrm{~cm}^{-1}\left(v_{2}\right)$ and 19,000-19,500 $\mathrm{cm}^{-1}\left(v_{3}\right)$, respectively. This corresponds to $\mathrm{D}_{4} \mathrm{~h}$ symmetry, the various bands may be due to ${ }^{4} \mathrm{~T}_{1} \mathrm{~g} \rightarrow{ }^{4} \mathrm{~T}_{2} \mathrm{~g}(\mathrm{~F}),\left(\mathrm{V}_{1}\right) ;{ }^{4} \mathrm{~T}_{1} \mathrm{~g} \rightarrow{ }^{4} \mathrm{~A}_{2} \mathrm{~g}(\mathrm{~F})$, $\left(v_{2}\right) ;{ }^{4} \mathrm{~T}_{1} \mathrm{~g} \rightarrow{ }^{4} \mathrm{~T}_{1} \mathrm{~g}(\mathrm{P}),\left(\mathrm{v}_{3}\right)$, respectively. Various bands do not show any regular pattern and are anion independent. Different ligand field parameters such as Dq, B, $\beta$ and $\beta \%$ were calculated for the complexes and have been listed in Table-1. The value of B is found to be $971 \mathrm{~cm}^{-1}$ for free cobalt(II) ion. The Nephelauxetic parameter $\beta$ calculated for the complexes is 0.376 . These values suggest the covalent nature of the metal ligand bond. The values of the $v_{2} / v_{1}$ ratio lie between 1.501.55 and suggest the octahedral structure for these complexes $[15,16]$.

Nickel(II) complexes: The magnetic moment of the nickel(II) complex was found to be at 3.25 B.M. It indicates a high spin configuration and showed the presence of two unpaired electrons in $\mathrm{Ni}(\mathrm{II})$ complex [17,18]. The electronic spectra of $\mathrm{Ni}$ (II) complex taken in DMSO solution show band at the low energy side in range $10,850-11300 \mathrm{~cm}^{-1}$. The other two bands observed in the region 15,900-16,100 $\mathrm{cm}^{-1}\left(\mathrm{~V}_{2}\right)$ and 25,600-27,100 $\mathrm{cm}^{-1}\left(\mathrm{~V}_{3}\right)$, were designated to ${ }^{3} \mathrm{~A}_{2} \mathrm{~g} \rightarrow{ }^{3} \mathrm{~T}_{1} \mathrm{~g}(\mathrm{~F})$ $\left(v_{2}\right)$ and ${ }^{3} \mathrm{~A}_{2} g \rightarrow{ }^{3} \mathrm{~T}_{1} \mathrm{~g}(\mathrm{P})\left(\mathrm{v}_{3}\right)$, respectively. This corresponds to $\mathrm{D}_{4 \mathrm{~h}}$ symmetry. Different ligand field parameters Dq, $\mathrm{B}, \beta$ and $\beta \%$ for these complexes are calculated and have been listed in Table-1. The value of B in case of free nickel(II) ion is $1040 \mathrm{~cm}^{-1}$. The Nephelauxetic parameter $\beta$ calculated for the complexes lies at 0.654 . These values depict the covalent character of the metal ligand bond. The values of the $v_{2} / v_{1}$ ratio at 1.504 suggest the octahedral structure of complexes [17-19].

Copper(II) complexes: The magnetic moment of copper(II) complex was found to be at 1.82 B.M. The electronic spectra of the $\mathrm{Cu}(\mathrm{II})$ complex show bands in the range 18,100$19,700 \mathrm{~cm}^{-1}$ which showed distorted octahedral geometry of the complexes [15]. The $d$-orbital energy level sequence for these complexes may be: $x^{2}-y^{2}>z^{2}>x y>x z>y z$ and the shoulder may be due to: $\mathrm{z}^{2} \rightarrow \mathrm{x}^{2}-\mathrm{y}^{2}\left({ }^{2} \mathrm{~B}_{1} \mathrm{~g} \rightarrow{ }^{2} \mathrm{~B}_{2} \mathrm{~g}\right)$ and the broad band showing both $\mathrm{xy} \rightarrow \mathrm{x}^{2}-\mathrm{y}^{2}\left({ }^{2} \mathrm{~B}_{1} \mathrm{~g} \rightarrow{ }^{2} \mathrm{Eg}\right)$ and $\mathrm{xy}, \mathrm{yz} \rightarrow \mathrm{x}^{2}-$ $\mathrm{y}^{2}\left({ }^{2} \mathrm{~B}_{1} \mathrm{~g} \rightarrow{ }^{2} \mathrm{~A}_{2} \mathrm{~g}\right)$ transition [20]. It suggests that the complex formed by macrocycles with $\mathrm{Cu}(\mathrm{II})$ metal was distorted octahedral [21].

Zinc(II) complexes: Due to fully filled $d$-orbitals, zinc complex is diamagnetic in nature. Zinc complex is consi-dered to have no $d-d$ transition as the electronic configuration of $\mathrm{Zn}^{2+}$ ion is $3 d^{10}, 4 s^{0}$. So no electronic spectra are available for zinc complexes.

Various ligand field parameters calculated in divalent metal complexes synthesized from hexamethylenediamine and ninhydrin are listed in Table-1.

Thermogravimetric analyses (TGA): The thermograms of $\mathrm{Fe}(\mathrm{II}), \mathrm{Co}(\mathrm{II}), \mathrm{Ni}(\mathrm{II}), \mathrm{Cu}$ (II) and $\mathrm{Zn}$ (II) complexes derived from hexamethylendiamine and 2,2-dihydroxyindane-1,3dione (ninhydrin) were recorded in $\mathrm{N}_{2}$ atmosphere in the temperature range of $10-500{ }^{\circ} \mathrm{C}$ with a heating rate of $10{ }^{\circ} \mathrm{C} /$ min. TGA thermograms for all the complexes showed single stage of thermal decomposition which runs in the temperature range of $250-300{ }^{\circ} \mathrm{C}$.

${ }^{13} \mathrm{C}$ NMR studies: ${ }^{13} \mathrm{C}$ NMR spectra were recorded on a Bruker Advance II 400 NMR spectrophotometer using dimethylsulphoxide as a solvent and TMS as reference. ${ }^{13} \mathrm{C}$ NMR spectra of the newly synthesized complexes from hexamethylenediamine and ninhydrin show 9 signals for 18 number of carbon atoms. The ${ }^{13} \mathrm{C}$ NMR spectra of hexamethylenediamine show a singlet peak at $3.41 \mathrm{ppm}$ due to carbon atoms of methyl groups, which remain same on complexation [22]. But, hexamethylenediamine shows a sharp peak at $42.1 \mathrm{ppm}$ (standard) due to $\mathrm{C}=\mathrm{N}$ group which found to be absent in ${ }^{13} \mathrm{C}$ NMR spectra of macrocyclic complexes. It indicates that $\mathrm{N}$ are involved in coordination of $\mathrm{N}$ with metal representing some uplift at $\sim 40.9$ ppm.

X-ray diffraction data: X-ray diffraction data were obtained from SAIF, CFL, Punjab University, Chandigarh using XPERT-PRO PANalytical with $\mathrm{Cu}$ as $\mathrm{X}$-ray source and scanning range $\left(0-80^{\circ} \mathrm{C}\right)$. All powder samples were scanned in the form of the discs. To protect from moisture, samples were collected in special sample tubes. The samples of divalent metal ions reveal amorphous nature by broadening peaks because sharp peaks indicate the crystalline nature. The unit cell of Ni(II) gives lattice constants $\mathrm{a}=10.500 \AA, \mathrm{b}=10.700 \AA, \mathrm{c}=11.900$ $\AA$, unit cell of $\mathrm{Zn}(\mathrm{II})$ gives $\mathrm{a}=11.803 \AA \mathrm{A}, \mathrm{b}=12.219 \AA$, $\mathrm{c}=$ $12.789 \AA$, unit cell of $\mathrm{Co}(\mathrm{II})$ gives $\mathrm{a}=10.426 \AA$, $\mathrm{b}=11.567$ $\AA, c=13.900 \AA$, unit cell of $\mathrm{Cu}(\mathrm{II})$ gives $\mathrm{a}=16.096 \AA$, $\mathrm{b}=$ $11.560 \AA, c=12.673 \AA$ and unit cell of Fe(II) gives $\mathrm{a}=12.512$ 
$\AA, \mathrm{b}=11.609 \AA, \mathrm{c}=16.893 \AA$. This data indicates monoclinic system for $\mathrm{Ni}(\mathrm{II})$ and $\mathrm{Zn}(\mathrm{II})$ and orthorhombic system for cobalt(II), copper(II) and iron(II) metal ions which is found to $b e$ in good agreement with the condition $\mathrm{a} \neq \mathrm{b} \neq \mathrm{c}$ and $\alpha=\gamma=90^{\circ} \neq \beta$ for monoclinic system and condition $\mathrm{a} \neq \mathrm{b} \neq \mathrm{c}$ and $\alpha=\beta=\gamma=90$ for orthorhombic system [23].

In the search of new and effective antimicrobial drugs, the metal complexes synthesized were screened against two Gram-positive bacteria: Bacillus subtilis (MTCC 8509), Bacillus stearothermophilus (MTCC 8508) and two Gram-negative bacteria: Escherichia coli (MTCC 51), Pseudomonas putida (MTCC 121) which was obtained from Institute of Microbial Technology, Chandigarh, India.

\section{in vitro Antibacterial activity}

Preparation of test samples: Test samples of the synthesized complexes were prepared in DMSO (dimethyl sulphoxide). The concentration ranges from 100 to $1 \mathrm{ppm}$.

Antimicrobial technique: In order to assess the antimicrobial activities, two Gram-positive bacteria Bacillus subtilis (MTCC 8509) and Bacillus stearothermophilus (MTCC 8508), two Gram-negative bacteria Escherichia coli (MTCC 51) and Pseudomonas putida (MTCC 121) were used. To evaluate the efficacy of newly synthesized complexes towards antimicrobial activities, Agar well diffusion technique [24] was used. Under aseptic conditions, in to the laminar flow chamber, $20 \mathrm{~mL}$ of MHA (Mueller- Hinton-Agar) medium was dispersed into presterilized petridishes. Once it solidifies, it was inoculated with microorganism (prepared according to the instructions of MTCC) suspended in peptone water. The media was punched with wells of $6 \mathrm{~mm}$ diameter and filled with different solutions prepared in different concentration (ppm) and labelled. Streptomycin and chlorampenicol antibiotics were used as positive control for comparison with macrocyclic complexes and DMSO used a negative control. Finally, the petridishes were kept in incubator at $37^{\circ} \mathrm{Cs}$ for $24 \mathrm{~h}$. On the next day, the diameter of circumference developed around the well was measured. Each experiment was done in triplicate for the determining MIC (minimum inhibitory concentration) [25-27]. The MIC was calculated by subtracting the value of diameter of DMSO (negative control) from the diameter of macrocyclic complexes (positive control) as per given in Table-2.

\begin{tabular}{lcccc}
\multicolumn{5}{c}{ TABLE-2 } \\
MIC DATA OF SYNTHESIZED \\
TRANSITION BIVALENT COMPLEXES \\
\hline \multirow{2}{*}{ Complexes } & \multicolumn{4}{c}{ Minimum inhibitory concentration } \\
\cline { 2 - 5 } & $\mathrm{A}$ & $\mathrm{B}$ & $\mathrm{C}$ & $\mathrm{D}$ \\
\hline$\left[\mathrm{Co}\left(\mathrm{C}_{30} \mathrm{H}_{24} \mathrm{~N}_{4} \mathrm{O}_{2}\right) \mathrm{Cl}_{2}\right]$ & 32 & $>64$ & $>64$ & 32 \\
{$\left[\mathrm{Ni}\left(\mathrm{C}_{30} \mathrm{H}_{24} \mathrm{~N}_{4} \mathrm{O}_{2}\right) \mathrm{Cl}_{2}\right]$} & 08 & 16 & 16 & 32 \\
{$\left[\mathrm{Fe}\left(\mathrm{C}_{30} \mathrm{H}_{24} \mathrm{~N}_{4} \mathrm{O}_{2}\right) \mathrm{Cl}_{2}\right]$} & 02 & 04 & 02 & 02 \\
{$\left[\mathrm{Cu}\left(\mathrm{C}_{30} \mathrm{H}_{24} \mathrm{~N}_{4} \mathrm{O}_{2}\right) \mathrm{Cl}_{2}\right]$} & $>64$ & $>64$ & $>64$ & 32 \\
{$\left[\mathrm{Zn}\left(\mathrm{C}_{30} \mathrm{H}_{24} \mathrm{~N}_{4} \mathrm{O}_{2}\right) \mathrm{Cl}_{2}\right]$} & 04 & 02 & 30 & 05 \\
$\mathrm{Chlorampenicol}$ & 02 & 02 & 04 & 02 \\
$\mathrm{Steptomycin}$ & 02 & 02 & 04 & 04 \\
\hline $\mathrm{A}=$ B. subtilis (MTCC 8509), B = B. stearothermophilus (MTCC \\
8508), C=P. putida (MTCC 121), D = E. coli (MTCC 51)
\end{tabular}

Proposed structure: Therefore, on the basis of different studies like elemental analysis, conductivity, magnetic suscep- tibilities, IR, ${ }^{13} \mathrm{C}$ NMR, XRD, electronic and mass spectra, octahedral geometry (distorted) as shown in Fig. 1 is suggested for all the divalent macrocyclic metal complexes.

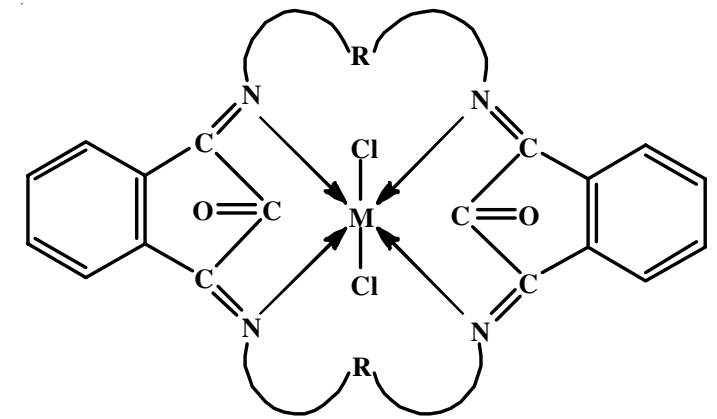

where $\mathrm{R}=-\left(\mathrm{CH}_{2}\right)_{6^{-}}, \mathrm{M}=\mathrm{Fe}(\mathrm{II}), \mathrm{Co}(\mathrm{II}), \mathrm{Ni}(\mathrm{II}), \mathrm{Cu}(\mathrm{II})$ and $\mathrm{Zn}(\mathrm{II})$

Fig. 1

\section{Conclusion}

For bivalent macrocyclic complexes, the template synthesis is a yield effective synthesis; these complexes can be assigned of distorted octahedral geometry. The complexes formed mainly are soluble in DMF and DMSO. XRD studies reveal amorphous nature of the complexes. $\left[\mathrm{Fe}\left(\mathrm{C}_{30} \mathrm{H}_{24} \mathrm{~N}_{4} \mathrm{O}_{2}\right) \mathrm{Cl}_{2}\right]$ complex of iron metal can be tested pharmaceutically for antibacterial activity for the above mentioned becteria. Most probably, antimicrobial agents act on 50S unit of the ribosome as the standard antibiotics do.

\section{ACKNOWLEDGEMENTS}

The authors are thankful to Director, SBS State Technical Campus, Ferozepur, IK Gujral Punjab Tech. University, Kapurthala and Director (SAIF) Punjab Univ. Chandigarh for providing the required technical support for analysis.

\section{CONFLICT OF INTEREST}

The authors declare that there is no conflict of interests regarding the publication of this article.

\section{REFERENCES}

1. Z.H. Chohan, H. Pervez, A. Rauf, K.M. Khan and C.T. Supuran, J. Enzyme Inhib. Med. Chem., 19, 417 (2004); https://doi.org/10.1080/14756360410001710383.

2. S. Fortuna, F. Fogolari and G. Scoles, Sci. Rep., 5, 15633 (2015); https://doi.org/10.1038/srep15633.

3. D.J. Cram, Angew. Chem. Int. Ed. Engl., 27, 1009 (1988); https://doi.org/10.1002/anie.198810093.

4. R. Sharma, Prabhat, R. Singh, S. Pawar and A. Chauhan, J. Am. Sci., 6, 559 (2010); https://doi.org/10.7537/marsjas060910.64.

5. Q. Zheng, H. Dai, E.M. Matthew, C. Malloy, C.Y. Pan, W.-H. Li, J. Am. Chem. Soc., 9, 46 (2005); https://doi.org/10.1021/ja054593v.

6. J. Forestier, J. Lab. Clin. Med., 20, 827 (1935).

7. W.O. Foye, T.L. Lemke and D.A. Williams, Foye's Principles of Medicinal Chemistry, Lippincott Williams \& Wilkins, p. 989 (2007).

8. G. Kapoor and S. Saigal Elongavan, J. Anaesthesiol. Clin. Pharmacol., 33, 3 (2017).

9. W.J. Geary, Coord. Chem. Rev., 7, 81 (1971); https://doi.org/10.1016/S0010-8545(00)80009-0. 
10. S. Chandra, R. Gupta, N. Gupta and S.S. Bawa, Transition Met. Chem., 31, 147 (2006); https://doi.org/10.1007/s11243-005-6194-5.

11. L.K. Gupta and S. Chandra, Transition Met. Chem., 31, 368 (2006); https://doi.org/10.1007/s11243-005-0002-0.

12. S. Chandra and S. Sharma, J. Indian Chem. Soc., 83, 988 (2006).

13. L.K. Gupta and S. Chandra, Spectrochim. Acta A Mol. Biomol. Spectrosc., 65, 792 (2006); https://doi.org/10.1016/j.saa.2005.12.042.

14. S. Chandra, R. Kumar, R. Singh and A.K. Jain, Spectrochim. Acta A Mol. Biomol. Spectrosc., 65, 852 (2006); https://doi.org/10.1016/j.saa.2006.01.005.

15. J.R. Ferraro, Low Frequency Vibrations of Inorganic and Co-Ordination Compounds, Part B, Wiley Interscience: New York, edn 5 (1997).

16. A.B.P. Lever, Inorganic Electronic Spectroscopy, Elsevier: Amsterdam, edn 2 (1984).

17. D.M.L. Goodgame, M. Goodgame, M.A. Hitchman and M.J. Weeks, Inorg. Chem., 5, 635 (1966); https://doi.org/10.1021/ic50038a029.

18. S. Chandra and A.K. Sharma, Spectrochim. Acta A Mol. Biomol. Spectrosc., 72, 851 (2009); https://doi.org/10.1016/j.saa.2008.12.022.

19. J. Cisterna, V. Artigas, M. Fuentealba, P. Hamon, C. Manzur, V. Dorcet, J.-R. Hamon and D. Carrillo, Inorg. Chim. Acta, 462, 266 (2017); https://doi.org/10.1016/j.ica.2017.04.001.
20. G.G. Mohamed, M.M. Omar and A.M.M. Hindy, Spectrochim. Acta A Mol. Biomol. Spectrosc., 62, 1140 (2005); https://doi.org/10.1016/j.saa.2005.03.031.

21. V.B. Rana, D.P. Singh, P. Singh and M.P. Teotia, Transition Met. Chem, 6, 36 (1981); https://doi.org/10.1007/BF01143465.

22. J.M. Al-Jeboori, Der Chem. Sinica, 7, 53 (2016).

23. P. Rathi, D.P. Singh and P. Surain, C.R. Chim., 18, 430 (2015); https://doi.org/10.1016/j.crci.2014.08.002.

24. NCCLS, Method for Dilution Antimicrobial Susceptibility Test for Bacteria that Grow Aerobically, Approved Standards, National Committee for Clinical Laboratory Standards, Villanova, PA, edn 5, M7-A5 (2000).

25. D. Greenwood, R. Slack and J. Peutherer, Medical Microbiology: A Guide to Microbial Infections: Pathogensis, Immunity, Laboratory Diagnosis and Control, ELST Publishers: Edinburgh, edn 15 (1997).

26. B. Mummed, A. Abraha, T. Feyera, A. Nigusse and S. Assefa, Bio-Med Res. Int., 2018, Article ID 1862401 (2018); https://doi.org/10.1155/2018/1862401.

27. M.B. Halli and R.B. Sumathi, Arab. J. Chem., 10(Suppl. 2), s1748 (2017); https://doi.org/10.1016/j.arabjc.2013.06.025. 